\title{
SIN PROTAGONISMO Y ENMUDECIDAS. LA MUJER EN EL FRANQUISMO Y SU SILENCIO EN EL ARTE ${ }^{1}$
}

\author{
Cristina García Cuesta ${ }^{2}$
}

\begin{abstract}
Sin protagonismo y enmudecidas. La mujer en el franquismo y su silencio en el arte Resumen: En España, durante los cuarenta años de la dictadura franquista, se reivindicó un modelo femenino madre-esposa, reproductora de hijos y de costumbres, donde la mujer como sujeto activo, dueña de sus actos y opiniones, no tenía cabida. El campo de las artes plásticas no fue una excepción. Las mujeres artistas españolas quedaron en un segundo plano en los principales movimientos artísticos, incluso muchas fueron olvidadas. Ese silencio impuesto acalló su creatividad e inquietudes; pero sin embargo, no fue para siempre. Gracias al acercamiento del feminismo al arte a partir de los años setenta del siglo XX, contra ese silencio, algunas mujeres artistas respondieron levantando sus voces con sus propias creaciones plásticas. Palabras clave: mujer, silencio, arte, feminismo, franquismo.
\end{abstract}

Repressed and silenced. Women during the Franco regime and their silence in the art Abstract: During the 40 years of the Franco dictatorship in Spain a new female role model developed: the mother/wife and reproducer of children who was also the custodian of cultural customs and values. The role of women as active subjects, owners of their own acts and options had no place in society at the time. The field of visual arts was no exception. Female Spanish artists were in the background in the main artistic movements and many were forgotten. That imposed silence wounds creativity and induces restlessness. From the 1970 s and thanks to feminism, some women artists responded against that silence and raised their voices with their own artistic creations.

Key words: woman, silence, art, feminism, Franco dictatorship.

“[...] Me gustas cuando callas porque estás como ausente. Distante y dolorosa como si hubieras muerto". (Neruda 1924).

De manera sistemática, los conceptos "mujer" y "silencio" se han mostrado vinculados en el discurso patriarcal, lo que ha generalizado y extendido un argumento en el que las mujeres aparecen enmudecidas, invisibles, a menudo controladas y atrapadas en un segundo plano respecto al varón protagonista de la Historia.

\footnotetext{
${ }^{1}$ Fecha de recepción: 06/04/2018.

Fecha de aceptación: 04/12/2018.

${ }^{2}$ Coordinadora y profesora de Historia del Arte en el Programa Interuniversitario de la Experiencia en la Universidad de Valladolid, Sedes de Palencia y Guardo. Miembro de la Cátedra de Estudios de Género de la Universidad de Valladolid. Doctoranda en Patrimonio Cultural y Natural. Historia Arte y Territorio (Universidad de Valladolid); $₫$ cristinagcuesta@gmail.com.
} 
La ausencia de sus palabras, fruto de una marcada tradición patriarcal influida por la religión y la cultura, relegó a las mujeres a ser consideradas como un objeto maleable en un universo masculino, lejos de ser un auténtico sujeto. Desde antiguo, en los textos bíblicos se hacía patente esa citada marginación del sexo femenino, sometida al hombre, el cabeza y portavoz de la familia: "Mujeres, estad sujetas a vuestros maridos, como conviene el Señor" (Colosenses 3, 18); "por lo que respecta a las mujeres, que vayan vestidas decorosamente [...] La mujer aprenda en silencio, con plena sumisión. No consiento que la mujer enseñe, ni domine al marido, sino que ha de estar en silencio. Pues primero fue formado Adán, y después Eva [...]" (Timoteo I, 2, 9-13); “enseñen a las jóvenes a que amen a sus maridos [...] a ser prudentes, puras, hacendosas en el hogar, amables, sujetas a sus maridos [...]" (Tito 2, 4-5).

Las palabras de estos pasajes se cumplieron a lo largo de los siglos. Con la Ilustración se constituyó un espacio social organizado entre la distinción de lo masculino dominante y lo femenino sumiso, dos esferas bien distintas que se corresponden con lo público y lo privado respectivamente (Cruzado 2011: 93). A los hombres se les condecía así el protagonismo en el ámbito público y el don de la palabra, y a las mujeres el silencio, como “ángeles del hogar” en la vida privada (Rodríguez 2016, 24). Este esquema se repetirá hasta el siglo XX, donde el colectivo de las mujeres, como acabamos de mencionar, fue relegado al ámbito doméstico, condenado al silencio, a callar su punto de vista y actuaciones, siendo excluidas del protagonismo social, político, religioso o cultural. Sin embargo, a finales del siglo XVIII, fue cuando un grupo de mujeres, tímidamente, tomaron conciencia de su situación y comenzaron la lucha por reivindicar su igualdad en todos los terrenos y su liberación, fraguándose en la 
mayor parte de los países de Europa y Norteamérica un movimiento social, político y cultural, después llamado feminismo.

En las últimas décadas del siglo XIX y las primeras del XX se consiguieron los primeros logros: la extensión del derecho al voto femenino, la mejora de la educación o la apertura de nuevos horizontes profesionales, entre otros. Además de la publicación de los primeros textos feministas que establecían ya las bases de la demanda femenina por la igualdad de derecho. Ejemplos de ello son la Declaración de Derechos de la Mujer y la Ciudadana (1791) redactada y presentada en la Asamblea Nacional Francesa por la Olympe de Gouges, donde se contemplaron por primera vez los derechos y las libertades las mujeres. El texto de la británica Mary Wollstonecraft titulado Vindicación de los Derechos de la Mujer (1972), en la que interpelará a los padres de la ilustración, condenando la educación que se daba a las niñas basada en el matrimonio, la crianza de los hijos y la domesticidad, y pidiendo al Estado un sistema de enseñanza primaria gratuita y universal para ambos sexos, que permitiese a las mujeres llevar una vida más útil y gratificante. La obra Los fundamentos sociales de la cuestión femenina (c. 1907) de Alejandra Kollontai, piedra angular de la comprensión marxista sobre los orígenes de la opresión de la mujer y la lucha por la emancipación de las mismas y de la clase trabajadora. Y también, entre otras, el discurso de Rosa de Luxemburgo pronunciado en las Segundas Jornadas de Mujeres Socialdemócratas en Stuttgart, el 12 de mayo de 1912, recogido en la obra El voto femenino y la lucha de clases, donde apelaba por el derecho político al voto de las mujeres y el fin de la opresión; o la obra Una habitación propia (1929) de la escritora británica Virginia Woolf, en el que la autora reflexiona sobre literatura y mujeres, y defiende la búsqueda de la independencia económica y 
personal de estas últimas, con la fin de hacerse un hueco en el panorama literario, y en otros campos de la vida.

En la España del siglo XIX, debido a la agitada situación política y al peso de la tradición, el feminismo tuvo una presencia mucho menor que en otros países europeos. Mujeres como Concepción Arenal (1820-1893) y Emilia Pardo Bazán (1851-1921) centraron sus reivindicaciones más en cuestiones de tipo social que político, tales como el derecho a la educación o al trabajo. No será hasta la proclamación de la II República en 1931, cuando se dieron las condiciones necesarias para que las mujeres tomasen el lugar que les correspondía en diferentes ámbitos de la cultura, la educación o la política, haciéndose portavoces de una multitud de cambios que se venían demandando desde hacía unas décadas. La II República fue crucial en la afirmación de los derechos de la mujer española, como el reconocimiento del voto femenino, el reconocimiento del matrimonio civil y el divorcio, la eliminación del delito de adulterio para las mujeres o el acceso en igual de condiciones legales a la vida pública y a la educación pública: "No podrán ser fundamentos de privilegio jurídico: la naturaleza, la filiación, el sexo, la clase social, la riqueza, las ideas políticas ni las creencias religiosas [...]” (Artículo 25, Constitución Española de 1931). Todo ello hace que surja un tipo de mujer moderna en núcleos urbanos, independiente e intrépida que se niega a seguir relegada al hombre. Este nuevo modelo de identidad femenina será seguido por un importante grupo de mujeres intelectuales con acciones sobresaliente en los avances sociales, políticos y culturales del período, como bien explica Shirly Mangini en su obra Las Modernas de Madrid. 
Algunas de esas mencionadas mujeres fueron Maruja Mallo, Remedios Varo, María Moliner, Rosa Chacel, Concha Méndez, Carmen de Burgos, María de Maeztu, Margarita Nelken, Federica Monseny, Clara Campoamor o Victoria Kent. Todas ellas irrumpieron con paso decidido en los círculos políticos e intelectuales del momento, ante el recelo de muchos de sus compañeros varones, que las tacharon de "sexualmente anormales": "Hay que destacar el carácter sexualmente anormal de estas mujeres que saltan al campo de la actividad masculina [...] Agitadoras, pensadoras, artistas, inventoras $[\ldots]$. Es pues indudable que la mujer ha de ser madre ante todo [...]" (Marañón 1927: 139-140): y de su innecesaria participación en la vida pública, ya "que el destino de la mujer no es la actividad [...] que la profunda intervención femenina en la historia no necesite consistir en actuaciones, en faenas, sino en la inmóvil, serena presencia de su personalidad" (Ortega y Gasset 1966: 13). Aquellos "misóginos informados" como Shirley Mangini llama a los intelectuales y profesionales de esta época, pretendían seguir manteniendo a la mujer apartada del ámbito público (Mangini 2001: 99-1002).

Sin embargo, fue fundamental el papel de estas mujeres y de otras muchas en el ámbito de la cultura. Sobre todo, cabe resaltar la ocupación del espacio público y la red de vínculos y relaciones establecidas entre ellas. Juntas se hicieron oír, y establecieron lazos intergeneracionales para rescatar a sus predecesoras y a la vez tendieron otros hacia el futuro, que sirvieran de guía para las generaciones venideras. Por primera vez, fueron conscientes de ser sujetos activos, y como afirma la productora y directora de cine Tania Balló "por primera vez, se presentan ante una sociedad que, aunque las rechace, se ve obligada a mirarlas" (Balló 2016: 12). 
Estas mujeres calificadas de modernas, se vieron reflejadas en las obras de las artistas plásticas españolas de esos años de la Vanguardia, como en las ilustraciones de La Venus Bolchevique (1932) de Delhy Tejero para la revista madrileña Crónica, que personificaba a una mujer independiente, sofisticada, vestida a la usanza de los nuevos tiempos, una mujer inteligente y desenvuelta, que puede tomar decisiones, que pilota aviones o conduce coches, una mujer que profesionalmente está a la altura de los hombres, con los que compite en el mismo terreno. Un mujer que forma parte de la sociedad, que sale de noche y se reúne con compañeras de estudios y con aquellas de inquietudes afines como observamos en la obra La Tertulia (1929) de Ángeles Santos, donde un grupo de cuatro chicas, de look notoriamente moderno, dialogan, leen y fuman, en un ambiente distendido ${ }^{3}$. También podemos ver a una mujer que exalta la cultura del ocio deportivo y los nuevos horizontes abiertos para la mujer dinámica, en contraposición a las prácticas conservadoras de la época, que la excluían de cualquier acción que pudiese arruinar su imagen delicada. Ejemplo de ello es la obra Ciclista (1927) de la artista Maruja Mallo, cuya protagonista ${ }^{4}$, una joven en bañador monta en bicicleta. La práctica de montar en bicicleta para las mujeres supuso todo un desafío, ya que ciertos sectores sociales lo consideraron poco honorable para ellas, incluso argumentaban que podía causarles daños físicos como la esterilidad o el aborto, y morales como propiciar su excitación sexual. Maruja Mallo, tomó la bicicleta como un símbolo da libertad y de lucha por la igualdad, desafiando a la sociedad machista que la rodeaba.

A pesar de que estas artistas escogieron trabajar en el marco de las vanguardias, por sus nuevos planteamientos de ruptura con la mentalidad conservadora, para poder

${ }^{3}$ El escenario es el pequeño piso de unas compañeras de clase de Ángeles que acudían al estudio de Cellino, las cuales serán las modelos del lienzo (Casamartini 2003: 37).

${ }^{4}$ Maruja Mallo tomó como modelo a su amiga Concha Méndez. 
expresarse con su obras y hacerse un hueco en el panorama artístico, van a encontrar contradicciones inherentes con estos principios: "se vieron atraídas inicialmente hacia el discurso antiburgués de los movimientos de vanguardia, pero tan solo para descubrir, con desencanto, que dichos movimientos no eran menos sexistas ni más tolerantes con las mujeres que las rígidas familias de las que habían escapado" (Mayayo 2003: 59). Estos movimientos artísticos de vanguardia no contaban con la mujer, la cual seguía encorsetada en los roles asignados de "musa", "ángel de hogar", "femme enfant", "fantasía sexual" o incluso como "femme fatale", como podemos comprobar al revisar la obra de Salvador Dalí y de otros artistas vinculados al surrealismo. Además, ninguna de ellas fue puesta en la lista oficial de miembros.

Como acabamos de comentar, se había fraguado un modelo de mujer moderna, una "nueva Eva", en una sociedad patriarcal que no compartía ninguna de sus actuaciones, pues anquilosada mente no aceptaba equiparse a ella, ni iba a permitir que ésta lo intentara. Todo ello junto con el estallido de la Guerra Civil en 1936 y los casi cuarenta años de la dictadura franquista, hicieron que se truncase finalmente el destino y aspiraciones de todas ellas. La sociedad posbélica del franquismo, restauró un modelo de feminidad extremadamente tradicional que recluía a las mujeres en el ámbito de lo privado y les negaba todos los derechos como personas adultas. El género femenino volvió a quedar enmudecido y sin discurso, es decir, nuevamente en silencio, y al margen de la sociedad. Como bien explica Rosalía Torrent, se trata de "un silencio impuesto, un silencio que lleva a la ocultación y al anonimato" (Torrent 2012: 202), de todas ellas.

\footnotetext{
${ }^{5}$ Véanse las obras de Erika Bornay (1990) y de Bram Dijkstra (1994). Ambas analizan los diferentes estereotipos asignados a las mujeres plasmados en el campo del arte y de la literatura.
} 
Bajo el largo periodo de la dictadura franquista (1939-1975) se interrumpió el camino de las mujeres hacia la emancipación, la igualdad y la ciudadanía iniciado al proclamarse la II República. El arcaico modelo de mujer impuesto por el régimen excluía al género femenino de toda actividad relacionada con el ámbito público, imponiéndose el hogar y la familia como únicos espacios autorizados. Por ley la mujer volvió a estar subyugada a la tutela del hombre, padre o esposo, sin tener identidad propia. Todos los derechos políticos y conquistas sociales fueron considerados impropios para el nuevo modelo de mujer, y rechazados sistemáticamente. Por ello se puede considerar que las mujeres españolas fueron doblemente represaliadas durante la guerra civil y el régimen dictatorial. Por un lado, por el mero hecho de ser mujeres, ya que perdieron los derechos y libertades alcanzadas durante la II República, siendo excluidas de la sociedad como ciudadanas de pleno derecho y relegadas al ámbito doméstico; y por otro lado, simultáneamente, muchas de ellas sufrieron físicamente la violencia represora por "rojas", siendo encarceladas, ejecutadas o duramente vejadas por sus ideales y creencias no afines al régimen, o simplemente padecieron el sufrimiento por ser las hermanas, viudas o madres de los vencidos.

En este panorama de desconcierto y represión, la gran mayoría de mujeres temerosas de ulteriores agravios enmudecieron y el silencio se adueñó de sus vidas, soportando calladamente lo que estaban sufriendo en su exilio interior: "¡Y si sabes quién te mató a tu hijo, te has de callar! ¡Y si sabes quienes te violaron, te has de callar! ¡Y si sabes quién te robó tu casa, te has de callar! [...]” (Salvador 2008: 31). El silencio fue el mejor aliado del régimen, para perpetuar los abusos y las desigualdades, y sembrar el miedo. Cuántas y cuántas veces, las mujeres tuvieron que escuchar las exclamaciones “¡cállate!” o “¡tú que sabrás!”, y morderse la lengua una y otra vez, ya 
que dar una respuesta suponía un castigo, o incluso, jugarse la vida. Ese simple y taxativo "¡cállate!”, que nos puede parecer inofensivo, es una de las formas de violencia que más anulan al ser humano (Torrent 2012: 201). Estas mujeres se vieron obligadas a silenciar sus opiniones frente a la palabra dominante de los hombres.

Sin embargo, no todo fue silencio absoluto, gracias a la voluntad de resistencia de unas pocas mujeres antifranquistas, la lucha continuaría en la clandestinidad, y, a veces, sin estar en la clandestinidad, algunas reivindicaron su derecho a la palabra. La poeta Gloria Fuertes aclamó que la muerte no era solo dejar de vivir, sino que también la "[...] muerte es quedarse solo, mudo y quieto y no poder gritar que sigues vivo", anticipándose como víctima del olvido y silencio de su obra y de su persona.

Las denuncias y demás reivindicaciones llevadas a cabo por las mujeres desafectas al régimen, junto con el paso de éstas por las cárceles franquistas, escasamente alcanzaron repercusión en la población; hasta el punto de que muchas de estas mujeres resultaron invisibles en el recuerdo de sus propios compañeros, como bien señala la presa política Juana Doña: "Se contaban epopeyas de las cárceles masculinas y las heroicidades de sus protagonistas [...] Rara vez se hablaba o escribía sobre las heroicidades de las luchadoras-mujeres" (Doña 1978: 15-16). Y es que el franquismo las silenció, excluyéndolas socialmente, "las descartó a su vez como 'objetos de historia' en la historia académica y el saber oficial al uso" (Hernández 2003: 19), levantando un muro de silencio en torno a las cárceles femeninas, a las presas y las actividades de protesta de todas ellas ${ }^{6}$.

“[...] Solo cuando las mujeres pudieron tener opción de romperlo [el silencio] consiguieron también utilizarlo para comunicar" (Torrent 2012: 202). Es el caso de

\footnotetext{
${ }^{6}$ Véase la obra de Gutmaro Gómez (2009).
} 
algunas mujeres artistas, que utilizaron su arte como herramienta para plasmar lo que sucedía en el país y a la vez para denunciar todo aquello que atentaba contra la humanidad, y sobre todo contra las mujeres. Hay que destacar algunas obras tempranas de la pintora Juana Francés (1926-1990) fundadora y participante del grupo El Paso, uno de los colectivos a través de los que se introdujo la abstracción en la España de postguerra. Especial interés tiene su obra, titulada Silencio (Figura I, 1953), que cronológicamente corresponde a la primera etapa pictórica de la artista, en la que enlaza con una figuración sintética y expresiva. Un estilo que la propia artista definía como "un expresionismo tranquilo", donde acostumbraba a retratar la soledad de los individuos, de las mujeres principalmente. La autora mostró gran interés por esta obra, pues como se recoge en sus declaraciones: "Me interesa mucho un cuadro que yo titulo SILENCIO; una mujer de medio cuerpo muy simple y su boca tapada con una mano; en actitud pensativa"7. Estas palabras de Juana Francés ponen el acento en el significado que trasmitía la propia obra, pues constituye una crítica a la situación social y política que se vivía en esos años en España, donde la censura, el miedo a hablar y a exponerse atemorizaban al ser humano. La censura del régimen había llegado a todos los rincones de la sociedad española, sobre todo a aquellos relacionados con actividades intelectuales: la prensa, el cine, la literatura, las artes plásticas o el teatro. Las libertades de expresión, de asociación y de manifestación no existían para los españoles, ni mucho menos para ellas.

\footnotetext{
${ }^{7}$ Entrevista realizada por Luis Blánquez Benito con motivo de su exposición en el Salón del Prado del Ateneo de Madrid, en 1959 (Molinos 2010).
} 


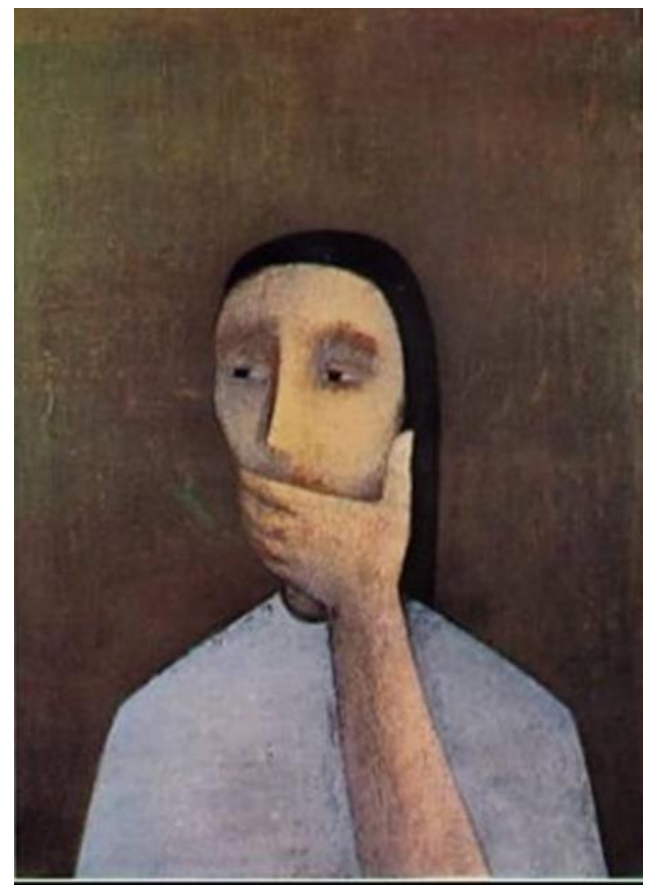

Figura I. Silencio (1953). Juana Francés. Óleo/lienzo. Colección particular

La protagonista de la obra es una figura femenina, hecho muy significativo, ya que las mujeres fueron doblemente castigadas y/o silenciadas, como hemos apuntado en líneas anteriores y volvemos a incidir en ello: por ser españolas, es decir, por vivir en España tras una guerra y durante una dictadura; y por su condición de individuo mujer. La figura se muestra recortada sobre un fondo neutro, sórdido, como el ambiente que se respiraba entre los artistas y toda la sociedad, sin condicionantes externos que la desviasen de la ideología conservadora. Efectivamente la presenta como una mujer del pueblo, sin destacar los rasgos sexuales.

De semblante triste y mirada perdida, no puede revelarse, aunque muestra su incomodidad y su miedo, pues una mano de proporciones desmesuradas cubre su boca, privando su libertad de expresión. En una primera lectura, la mano que tapa su boca parece de la propia mujer en un acto de autocensura o de miedo: “[...] La desconfianza y el temor cerraban puertas y agarrotaban gargantas, aun cuando la protesta y la 
necesidad de gritar su rebeldía, su amargura, desbordara tantos corazones dolientes, torturados, humillados siempre" (Roig 2013: 11). Pero en una segunda mirada, no queda claro si esa mano es suya o no. En efecto, más parece de otra persona que la silencia, de un hombre en concreto o de la propia sociedad, ya que los mandatos desde el patriarcado que silenciaban y oprimían a las mujeres se hacía cada vez más fuertes, como se pone en evidencia en estas palabras de Pilar Primo de Rivera: "Todos los días deberíamos dar gracias a Dios por habernos privado a la mayoría de las mujeres del don de la palabra, porque si lo tuviéramos, quien sabe si caeríamos en la vanidad de exhibirlo en las plazas"8 (Lafuente 2003: 172). Es un cuadro especialmente desolador por la presencia "invisible" que silencia a la mujer.

Esa presencia "invisible" hará todo lo posible por ocultar y silenciar los nombres y obras de una generación de artistas mujeres, las llamadas propiamente como hijas de la postguerra, que comienzan a exponer en los años cincuenta, participando en la renovación de la plástica española. Entre ellas se encuentra la citada Juana Francés (1924-1990), Elvireta Escobio (1932-) ambas integrantes del grupo El Paso, Jacinta Gil (1917-2014) miembro de Parpalló, María Francisca Dapena (1924-1995) del grupo Estampa Vizcaya, Amalia Avia (1930-2011), Esperanza Parada (1928-2011) o Carmen Laffón (1934-) entre otras muchas. Así lo confirman las palabras de Pilar Muñoz, apuntando que la literatura escrita sobre historia del arte en España no muestra sus obras, ni refleja la contribución de estas mujeres al ámbito general del arte, quedando sistemáticamente silenciadas y por lo tanto olvidadas (Muñoz 2003: 251). Un injusto olvido, pues sus trabajos resultaron fundamentales en las siguientes generaciones de artistas mujeres, abriendo camino en un difícil y angosto mundo, el del arte.

\footnotetext{
${ }^{8}$ Palabras de Pilar Primo de Rivera, extraídas de un discurso ante las participantes en el Primer Consejo Nacional de Magisterio en febrero de 1943.
} 


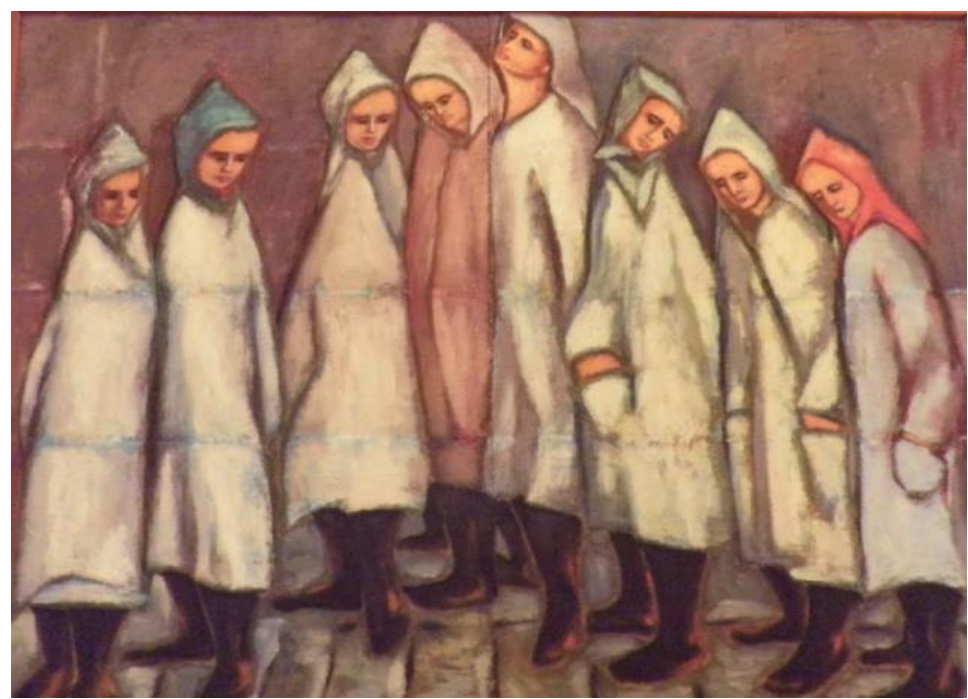

Figura II. Presas (1962). Mª Francisca Dapena. Óleo sobre lienzo Título

El silencio y la represión fueron también representados en la obra plástica de María Francisca Dapena (1924-1995), cuya vida desde la década de 1950 estuvo indisolublemente unida al Partido Comunista, por lo que la temática sociopolítica fue el centro de su obra durante esa etapa. Sus lienzos y grabados se tornaron en una obra de denuncia social, criticando la situación de los mineros, los pescadores, las madres con hijos..., es decir, una constante defensa del ser humano, sobre todo de aquellos y aquellas pertenecientes a las clases sociales más desfavorecidas. Su amistad e intereses comunes con Agustín Ibarrola, y con otros artistas vascos del momento, le llevaron a formar parte del grupo Estampa Popular de Vizcaya, un movimiento con un planteamiento vanguardista, que vinculaban el realismo plástico y los objetivos sociales. $\mathrm{Su}$ participación activa en huelgas y movimientos reivindicativos, provocaron su detención y encarcelamiento en 1962 en el Penal de Mujeres de Alcalá de Henares en Madrid. Sus compañeras presas pasaron a ser las protagonistas de sus pinturas y grabados durante su reclusión entre 1962 y 1964. Las representó cabizbajas, de mirada ausente, con las características batas largas y las botas negras, cubiertas sus cabezas con 
una capucha (Figura II), escondiendo la injusticia de su agonía, reproduciendo así la situación de doble opresión en que vivía la mujer.

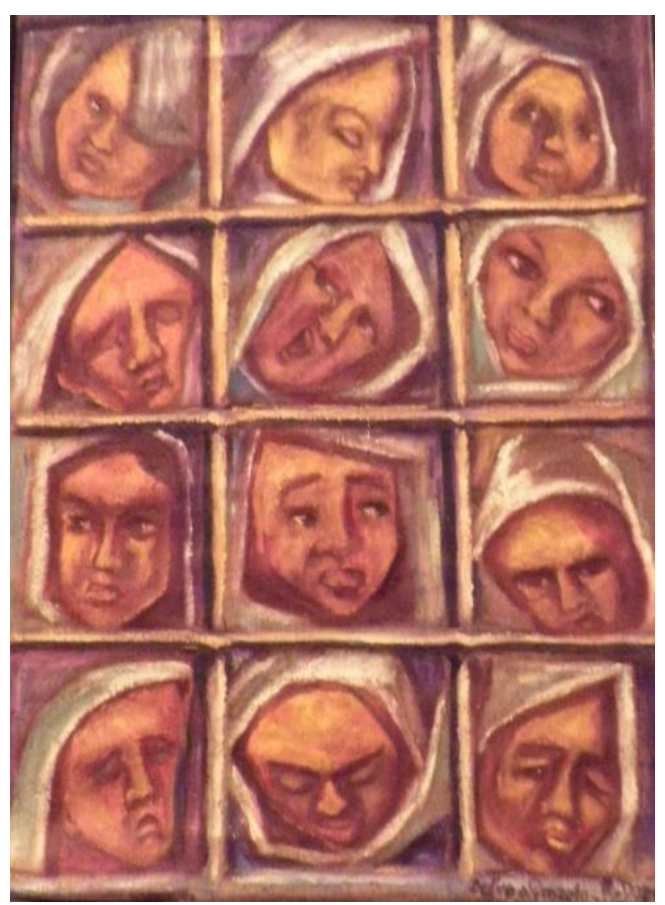

Figura III. Presas (1962-1964). Ma Francisca Dapena. Óleo sobre lienzo

Cabe mencionar su obra Presas (Figura III), compuesta por doce retratos individuales de reclusas ${ }^{9}$, ensamblados entre sí, y cuya delimitación entre uno y otro, simula las rejas de una celda. Se hallan prisioneras en una cárcel, enjauladas, oprimidas por el brazo violento del franquismo, lo cual se plasma en la obra, al quedar cada rostro encapuchado encajonado en un espacio excesivamente angosto y opresivo. De semblantes afligidos, todas a excepción de una, aprietan fuertemente su boca, por miedo a que sus palabras retornasen en castigo: "Contemplé rostros ojerosos, caras deslavazadas, cabellos chorreando sudor, bocas pálidas [...] éramos una masa de carne inmovilizada [...]" (Dapena 1978: 50). Entre todas ellas, tan sólo un grito, un halo de vida, una boca abierta que pide libertad, justicia, que exclama al mundo para que todos

\footnotetext{
${ }^{9}$ De forma individual consiguió enviar al exterior. Entrevista realizada a Gaizka Villate Dapena (25 de abril de 2016), hijo de Francisca Dapena, en Bilbao.
} 
se enteren de lo que están padeciendo estas mujeres: “¿Qué sentido tendría mi cárcel si, al liberarme, callo? ¿Cómo justificaría mi delito social si no explico lo que he visto y veo y sufro?" (Dapena 1978: 82). Esta figura es una excepción entre el conjunto de bocas cerradas, de idénticas mujeres silenciadas, sin palabra, como siempre se las había representado. Por eso, la mujer que abre su boca gritando al cielo, que eleva su protesta, es una heroína del pueblo, y tiene su correlato en la Cabeza de Montserrat gritando (c. 1942) del escultor Julio González.

Las voces dormidas (Chacón 2002) de todas aquellas mujeres, artistas o no, activistas o no, pedían a gritos ser rescatadas del silencio. "Explica a los de la calle lo que has visto aquí [...] Que los de la calle sepan”, así se despedía una compañera reclusa de Mercedes Núñez Targa al abandonar la cárcel de Ventas. La citada Margarita Núñez Targa (1911-1986) ${ }^{10}$, Jacinta Gil Roncalés (1917-2014) ${ }^{11}$, Juana Doña Jiménez (1918-2003) ${ }^{12}$, María Francisca Dapena (1924-1995) ${ }^{13}$, Eva Forest (19282007) ${ }^{14}$ o Lidia Falcón (1934-) ${ }^{15}$ fueron algunas de esas mujeres comprometidas en las

\footnotetext{
${ }^{10}$ Escribió en el exilio Cárcel de Ventas, el cual fue publicado por primera vez en París en 1967, con un prólogo del poeta Marcos Ana. El libro, según palabras de la autora, está dedicado a los «hijos de los vencedores y de los vencidos» y relata su paso por la prisión madrileña de Ventas entre 1940-1942. La autora quiere que conozcamos lo que sucedió y que no mueran en el olvido las vivencias y sufrimientos de tantas mujeres que lucharon con desigual fortuna por la libertad.

${ }^{11}$ Jacinta Gil escribió muy al final de su vida Vivir en las cárceles de Franco: testimonio de una presa política, que recoge parte de su diario escrito en 2005.

${ }^{12}$ La novela-testimonio de Juana Doña Jiménez, Desde la noche y la niebla, fue terminada en 1967 cinco años después de su último excarcelamiento, esperando a ser publicada hasta 1978. Su obra, tras haber pasado dieciocho años en las cárceles de Franco, "apunta al sesgo perverso de la memoria que los propios antifranquistas habían elaborado de su lucha, de sus epopeyas, de su épica resistente", en (Hernández 2015: 287).

${ }^{13}$ María Francisca Dapena compiló sus cuadernillos y apuntes a la salida de la cárcel, pero tuvo que esperar para verlo publicado hasta una fecha tan tardía como enero de 1978, con el revelador título iSr. Juez! (soy presa de Franco...).

${ }^{14}$ Acusada de colaborar con ETA, pasó casi tres años en prisión preventiva en Yeserías en el Barrio de Delicias en Madrid (1974-1977). Allí comenzó a escribir Diario y Cartas desde cárcel, donde trata el tema de la mujer militante y su situación en las cárceles franquistas; y Testimonios de lucha y de resistencia, una recopilación de testimonios de vivencias en la cárcel de Yeserías en los años 70.

${ }^{15}$ En el infierno fue el testimonio escrito de Lidia Falcón durante su condena en la prisión de Yeserías (Madrid) a partir de 1974. Desde una perspectiva feminista, Falcón abordaba en esta obra la vivencia carcelaria histórica de las mujeres, tan distinta de los hombres, durante los últimos momentos de la dictadura.
} 
luchas sociales, que cumplieron condenas acusadas de subversivas y de auxilio a la rebelión. Todas ellas sintieron la necesidad de dejar constancia escrita de su vida en la prisión y de la del resto de mujeres encarceladas, pues ellas eran el fruto palpable de las desigualdades de género. Para Dapena “conocer a estas mujeres en la cárcel es conocer sus hambres, las palizas de los chulos. Las muertes de sus hijos a manos de las patronas [...] Por ellas supe de la vida más de lo que pudiera imaginar" (Dapena 1978: 78, 20); e incluso afirmó que "de no haberme encarcelado, no hubiera conocido el engaño y no hubiera conocido a sus víctimas" (Dapena 1978: 93).

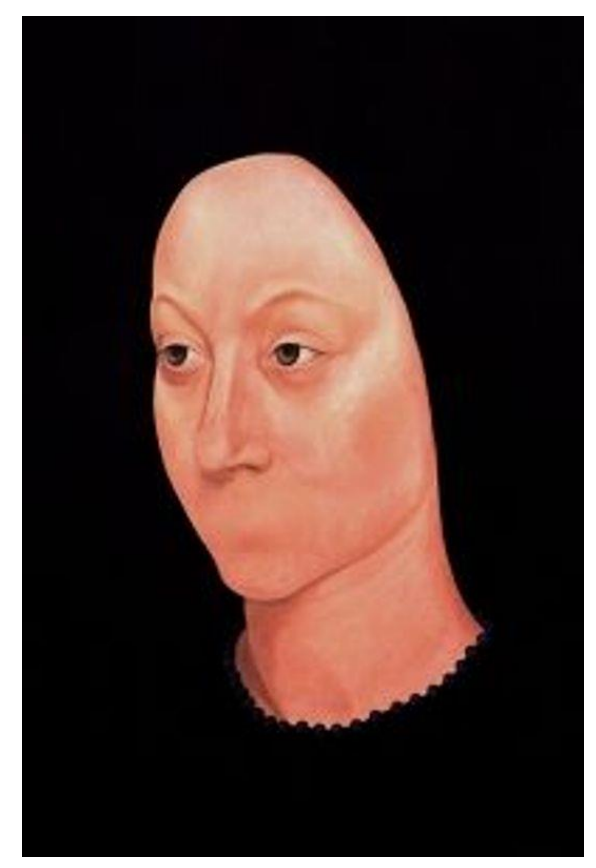

Figura IV. Sin Título en la Serie Monstruas (1994). Marina Núñez. Óleo sobre lino

En pleno franquismo ya había en España un protofeminismo artístico que denunciaba el silencio, las injusticias y la violencia contra la condición femenina. Estas discriminaciones fueron visualizadas por algunas artistas mujeres sobre todo a partir de los años 70, hecho que se acentuó a la muerte del dictador. Esther Boix (1923-2014) y María Antonia Dans (1922-1988) fueron algunas de estas creadoras que pusieron de manifiesto en sus obras las desigualdades de las mujeres en el trabajo (Dona que frega 
de 1963 o Tenda de 1972 respectivamente). El tema de la violencia machista se vio plasmada en obras como la serie La descarga (1975-1977) de Marisa González (1945-). Más tardíamente la represión y el silencio impuesto a las mujeres fueron protagonistas en algunas series de Marina Núñez (1966-), imágenes de mujeres sin boca como Sin título de la Serie Monstruas (Figura IV, 1994), otras amordazadas como en Dona Silenciosa (2004) de Amelia Riera (1934-), con la boca cosida, tapada y a veces oprimida por una enorme mano que no deja emitir palabra alguna. Ilustrando este último ejemplo podemos señalar las piezas escultóricas tituladas Reprimida (Figura V, 1984) y Mujer colmada (Figura VI, 1982) de la artista plástica Castorina Fe Francisco (1928-).

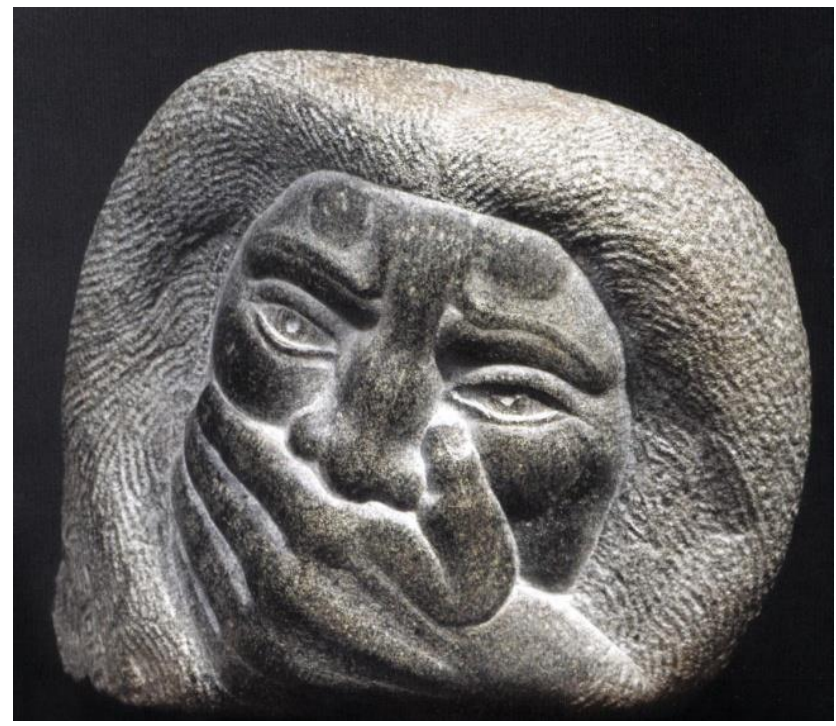

Figura V Reprimida (1984). Castorina F. Francisco. Talla en piedra moralina del Teleno.

Las citadas obras de Castorina son dos piezas de pequeño tamaño, en bulto redondo, con un planteamiento expresionista, tanto por el efecto de las texturas, como por los gestos y el acabado primitivo de las formas. Con Reprimida (Figura V, 1984) formula una crítica a la falta de libertades de las mujeres, a través de una cabeza de mujer, de semblante contenido, con los ojos muy abiertos, el ceño fruncido y la boca tapada por una desproporcionada mano que ocupa el lugar del cuello. Una composición 
que ya la artista Juana Francés en pintura había representado en su obra Silencio de 1953 (Figura I) también con el mismo propósito de crítica a la situación política y social de España. La expresión de angustia tanto del rostro como de la disposición de brazos y manos de la figura femenina cobran cotas muy elevadas en Mujer colmada (Figura VI, 1982). Un fragmento de piedra del que surge una figura femenina sentada sobre sí misma, con las piernas flexionadas, el torso desnudo, los brazos alzados, sin sobresalir del bloque pétreo, agarrándose los hombros, empequeñeciéndose ante el mundo. La cabeza se pliega hacia atrás, mirando hacia arriba, con boca entreabierta en gesto de dolor y/o súplica.

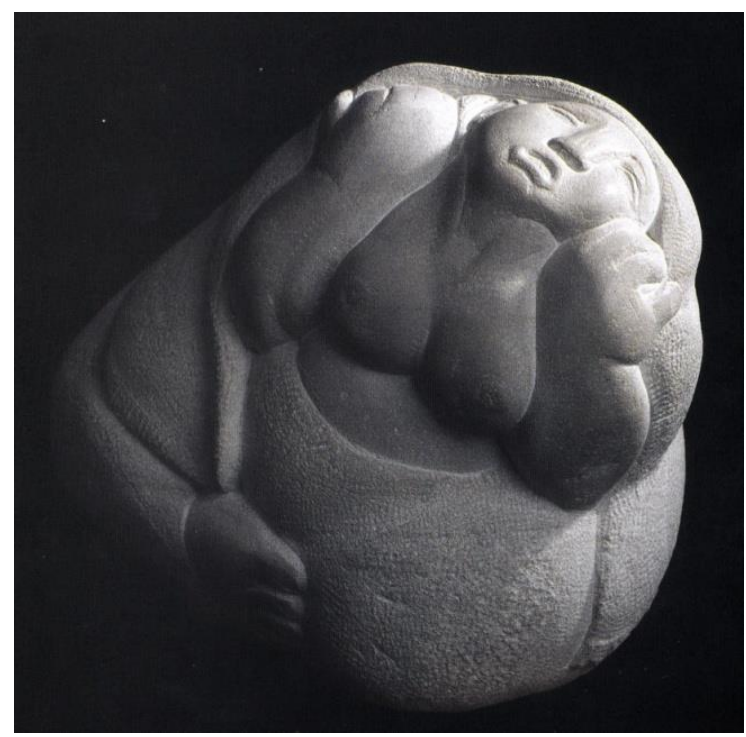

Figura VI. Mujer colmada (1982). Castorina F. Francisco. Talla en piedra

La fuerza de estas imágenes y demás testimonios escritos supusieron un grito ante el silencio, un testimonio de "denuncia de la sociedad, instituciones y personas que consienten tanta injusticia" (Dapena 1978: 224). Un duro trabajo que, sin embargo, a día de hoy todavía no se ha completado, ya que a las mujeres se las sigue callando y silenciando en multitud de ocasiones y en determinados contextos, y "en los que se respeta su voz, tampoco se libra de frecuentes exabruptos que no hacen más que poner 
de manifiesto a una conciencia misógina que no acaba de extinguirse" (Torrent 2012: 201) aún en el siglo XXI.

\section{Referencias bibliográficas}

Alario, Teresa. 2008. Arte y feminismo. San Sebastián: Nerea.

Aliaga, Juan Vicente y Mayayo, Patricia (Coord.). 2013. Genealogías feministas del arte español (1960-2010). León: Ed. This Side Up. Museo de Arte Contemporáneo de León.

Balló, Tania. 2016. Las sinsombrero. Sin ellas la historia no está completa. Barcelona: Espasa.

Barranquero, Encarnación (ed). 2010. Mujeres en la Guerra Civil y el Franquismo. Violencia, silencio y memoria en los tiempos difíciles. Málaga: CEDMA.

Bornay, Erika. 1990. Las hijas de Lilith. Madrid: Ensayos de Arte Cátedra.

Casamartini, Josep. 2003. Ángeles Santos, un mundo insólito en Valladolid. Catálogo de la exposición celebrada en el Museo Patio Herreriano de Arte Contemporáneo Español en Valladolid.

Cruzado, Ángeles. 2011. “Cuerpos encerrados. De cómo las mujeres reales e imaginadas son confinadas en 'su' espacio". In Corpore Dominae: cuerpos escritos / cuerpos proscritos. Ed. Dolores Ramírez Almazá. Sevilla: Arcibel Editores.

Chacón, Dulce. 2002. La voz dormida. Madrid: Alfaguara.

Dapena, Ma Francisca. 1978. ¡Sr. Juez! (soy presa de Franco). San Sebastián: Haramburu.

Dijkstra, Bram. 1994. Ídolos de perversidad. La imagen de la mujer en la cultura de fin de siglo. Madrid: Debate

Doña, Juana. 1978. Desde la noche y la niebla (mujeres en las cárceles franquistas). Novela-testimonio. Madrid: Ediciones de la Torre.

Falcón, Lidia. 1977. En el infierno. Ser mujer en las cárceles de España. Barcelona: Vindicación feminista.

Forest, Eva. 1975. Diario y Cartas desde cárcel. Paris: Edition de Femmes. 1977. Testimonios de lucha y de resistencia. Hendaye: Ediciones Mugalde.

Gil, Jacinta. 2007. Vivir en las cárceles de Franco: testimonio de una presa política. Valencia: Servicio de Publicaciones de la Universidad de Valencia. 
Gómez, Gutmaro. 2009. El exilio interior. Cárcel y represión franquista en España (1939-1950). Madrid: Taurus.

Hernández, Fernando. 2003. Mujeres encarceladas: la Prisión de Ventas, de la República al Franquismo (1931-1941). Madrid: Marcial Pons.

. 2015. "Juana Doña y el manantial de la memoria. Memorias de las cárceles franquistas de mujeres (1978-2007)". Revista Arenal, 22.2 (julio-diciembre 2015): 287. http://revistaseug.ugr.es/index.php/arenal/article/view/ 2386/3842 [ [ 1 de enero de 2016].

Lafuente, Isaías. 2003. Agrupémonos todas: lucha de las españolas por la igualdad. Madrid: Aguilar.

Mangini, Shrily. 2001. Las modernas de Madrid. Las grandes intelectuales españolas de la vanguardia. Barcelona: Península

Marañón, Gregorio. 1927. Tres ensayos sobre la vida sexual. Sexo, trabajo y deporte. Maternidad y feminismo. Educación sexual y diferencia sexual. Madrid: Biblioteca Nueva.

Mayayo, Patricia. 2003. Historias de mujeres, historias del arte. Madrid: Ensayos Arte Cátedra.

Molinos, Natalia. 2010. La artista alicantina Juana Francés: estudio crítico de su obra. Tesis doctoral. http://www.mav.org.es/documentos/ensayos\%20ene2013/Juana\% 20Frances\%20Tesis_Natalia\%20Molinos-2.pdf [2 de julio de 2017].

Morcillo, Aurora. 2015. En cuerpo y alma. Ser mujer en tiempos de Franco. Madrid. Siglo XXI.

Muñoz, Pilar. 2003. Mujeres españolas en las artes plásticas. Madrid: Síntesis.

Neruda, Pablo (2010, $1^{\text {o }}$ edición 1924). "Poema XV”, en Veinte poemas de amor y una canción desesperada. Barcelona: Seix Barral.

Núñez, Mercedes. 1967. Cárcel de Ventas. París: Editions de la Librarie du Globe.

Ortega y Gasset, José. 1966. Estudios sobre el amor. Madrid: Revista de Occidente.

Rodríguez, Sofía. 2016. "El silencio femenino como insumisión (s. XIX y XX). Resistencias frente a la ley del silencio". Andalucía en la Historia, 32: 24-29.

Rodrigo, Antonina. 2013. Mujeres olvidadas. Las grandes silenciadas de la República. Madrid: La Esfera de los Libros.

Salvador, Amparo. 2008. "Mujeres en el franquismo". Revista Pueblos, 34: 31.

Sánchez, Pura. 2014. "Exilio interior femenino y supervivencia durante la dictadura". Homenaje a Carmen de Michelana. Jaén: Universidad de Jaén.

Torrent, Rosalía. 2012. "El silencio como forma de violencia. Historia del arte y mujeres". Arte y políticas de identidad, 6 (Nuevas violencias de género, cultura 
visual y globalización. La política de las imágenes). Murcia: Servicio de publicaciones de la Universidad de Murcia. 